Reflection Article/Essay

\title{
About new forms of colonization in occupational therapy. Reflections on the Idea of Occupational Justice from a critical-political philosophy perspective ${ }^{1,2}$
}

A propósito de nuevas formas de colonización en terapia ocupacional. Reflexiones sobre la Idea de Justicia Ocupacional desde la perspectiva de una filosofia politica crítica

Sobre as novas formas de colonização em terapia ocupacional. Reflexöes sobre a ideia de Justiça Ocupacional na perspectiva de uma filosofia política critica

Alejandro Guajardo Córdoba ${ }^{\text {(D) }}$

${ }^{a}$ Universidad de Santiago de Chile, Chile, Santiago.

How to cite: Guajardo Córdoba, A. (2020). About new forms of colonization in occupational therapy. Reflections on the Idea of Occupational Justice from a critical-political philosophy perspective. Cadernos Brasileiros de Terapia Ocupacional. Ahead of Print. https://doi.org/10.4322/2526-8910.ctoARF2175

\begin{abstract}
$\underline{\text { Abstract }}$
Based on a critical political philosophy position, this is a reflection of the emergence of a variety of new concepts in North-Eurocentric occupational therapy. In this new prolific and technocratic grammar, the idea of Occupational Justice (OJ) has largely resulted in this scenario, as well as in other spaces on the periphery of the global world system of the profession, particularly in academia. I maintain that the idea of Occupational Justice (OJ) has become a new form of epistemic and cognitive colonization of the profession, which operates under universalist, essentialist, liberal assumptions, typical of modern Eurocentric rationality. This idea of a single, homogeneous justice, associated with the notion of occupation would allow occupational therapy (OT) to methodologically fulfill its professional and disciplinary work structured under scientific assumptions and respond appropriately to the new complexities of its work. In the development of the text, the idea of justice is recognized as a notion that derives from political philosophy. The definition of justice
\end{abstract}

\footnotetext{
${ }^{1}$ This manuscript corresponds to the full text of the summary presented in the inaugural panel of the X Argentine Congress and XIll Latin American Congress of Occupational Therapy, in the city of Tucumán, Argentina, in September 2019.

${ }^{2}$ The writing of this article assumes the perspective of human rights and sexual and gender diversity established in the Manual Mobilizing Diversity of Amnesty International, which indicates that in the writing of a text "[...] the letter $\mathrm{x}$ is used to propose a that includes all those people who identify with the various expressions and gender identities" (Amnistía Internacional, 2019, p. 3).
} 
and fairness is presented, according to political philosophy in its liberal and communitarian aspects. The scope of the idea of OJ and its colonial implications are delimited, an idea of Justice is proposed based on a critical ethical-political criterion, not an instrumental technical one, based on the idea of good living, under a pluricultural logic, of an anti-capitalist, communitarian order and that it materializes an expression of situated human rights, based on the recognition of difference.

Keywords: Occupational Therapy, Politics, Social Justice, Colonialism, Latin America.

\section{$\underline{\text { Resumen }}$}

Se reflexiona, desde una lectura de la filosófica política crítica, la emergencia de una variedad de nuevos conceptos en la terapia ocupacional nor-eurocéntrica. En esta prolífera nueva gramática tecnocrática, la idea de Justicia Ocupacional (JO) ha resultado ampliamente incidente en dicho escenario, así como en otros espacios de la periferia del sistema mundo global del oficio, en particular en la academia. La idea de Justicia Ocupacional (JO), sostengo, se ha constituido en una nueva forma de colonización epistémica y cognitiva de la profesión, la que opera bajo supuestos universalistas, esencialista, liberales, propios de la racionalidad moderna eurocéntrica. Esta idea de una justicia única, homogénea, asociada a la noción de ocupación permitiría a la terapia ocupacional (TO) cumplir metodológicamente su quehacer profesional y disciplinar estructurado bajo los supuestos científicos y así responder de manera apropiada a las nuevas complejidades de su quehacer. En el desarrollo del texto, se reconoce la idea de justicia como una noción que deriva de la filosofía política. Se distingue qué es lo justo y las teorías de justicia derivadas de dicha definición en este campo filosófico, en sus vertientes liberales y comunitaristas. Delimitados los alcances en la idea de JO y sus implicancias coloniales, se propone una idea de Justicia basada en un criterio ético político crítico, no técnico instrumental, sustentado en la idea de buenos vivires, bajo una lógica pluricultural, de orden anticapitalista, comunitarista y que materialice una expresión de derechos humanxs situados, fundamentados en el reconocimiento de la diferencia.

Palabras clave: Terapia Ocupacional, Política, Justicia Social, Colonialismo, América Latina.

\section{$\underline{\text { Resumo }}$}

Reflete, a partir de uma leitura da filosofia política crítica, a emergência de uma variedade de novos conceitos na terapia ocupacional do centro-norte. Nesta proliferaçáo de uma nova gramática tecnocrática, a ideia de Justiça Ocupacional (JO) tem sido amplamente incidente nesse cenário, bem como noutros espaços da periferia do sistema global da profissão, particularmente na academia. Mantenho que a ideia de Justiça Ocupacional (JO) se tornou uma nova forma de colonizaçáo epistémica e cognitiva da profissão, que funciona sob pressupostos universalistas, essencialistas e liberais, típicos da moderna racionalidade eurocêntrica. Esta ideia de uma justiça única e homogénea, associada à noção de ocupação, permitiria à terapia ocupacional (TO) cumprir metodologicamente a sua tarefa profissional e disciplinar estruturada sob os pressupostos científicos e assim responder adequadamente às novas complexidades do seu fazer. No desenvolvimento do texto, a ideia de justiça é reconhecida como uma noçâo derivada da filosofia política. É feita uma distinção entre o que é justo e as teorias de justiça derivadas dessa definição neste campo filosófico, nos seus aspectos liberais e comunitários. Delimitada na ideia de Justiça Ocupacional e nas suas 
implicações coloniais, propóe-se uma ideia de Justiça baseada num critério éticopolítico crítico, não instrumental técnico, sustentada na ideia de um bom viver no plural, sob uma lógica pluricultural, de ordem anticapitalista, comunitária e que materializa uma expressão de direitos humanos situados, baseada no reconhecimento da diferença.

Palavras-chave: Terapia Ocupacional, Política, Justiça Social, Colonialismo, América Latina.

\section{As an Introduction}

Regarding the X Argentine Congress and XIII Latin American Congress of Occupational Therapy, 2019, the proposal of "Living with Diversity, building Occupational Justice from Latin America" has been debated.

This paper is a possible point of view of analysis, as surely there can be many. The intention is to establish dialogues, but also controversies in the sense of confluence of dissident voices (Díaz, 2020) before the idea of Occupational Justice. This point of view is available from a particular place, the one that I have assumed in my personal development, as in my professional and academic career since the 1980s, which refers to an ethical, political, reflective, and critical praxis of the profession in the human rights (HR) area. I assume this perspective from the historical materialist foundation as the politicalphilosophical tradition that, translated into the field of social sciences, understands that the production of life is the result of concrete social conditions and relationships of existence and that humanity, freedom and in this case, justice is only possible to the extent that the currently dominant world system is overcome - in the sense of transformation. In this world is where human suffering, inequities, violence, the non-right to good living, and a cultural plurality of justice are sheltered. It implies that the work developed from a job is primarily ethical and political, which precedes, and at the same time determines, the professional and disciplinary work. I articulate this critical option with the so-called South perspectives, in particular with decolonial Latin American readings.

With this scope, to think about what Justice can be in occupational therapy is interesting since it opens the possibility to debate the ethical and political in the profession, dimensions that have already been addressed for several years in the Latin American region and, particularly in the southern cone. Proof of this can be found in the XV World Congress of Occupational Therapy held in Chile in 2010 referring to human rights, in the contributions raised by the Social OT, in the conceptual and practical developments of the so-called Critical OT, in the Community OT, as well as in various practical and theoretical expressions of occupational therapy based on human rights in different contexts and periods: State terrorism, migration, psychiatric reform, poverty, social exclusion in its various expressions, in community-based rehabilitation, collective health, among other. In all of them, the issue of justice has been at stake ${ }^{3}$.

\footnotetext{
${ }^{3}$ In this regard, there is a very interesting regional productivity that weaves into its writing the theme of justice, human rights, occupational therapy in different situations of social reality. Among the vast list of texts, I detail here some: Simó et al. (2016), Lopes \& Malfitano (2016), Navarrete et al. (2015), Santos \& Donatti (2014), Grupo Ocupación y Realización Humana (2011), Oyarzun et al. (2012), Paganizzi (2007). I make special mention on the subject of human rights, justice and occupational therapy, to the work developed in the Center for Mental Health and Human Rights - CINTRAS, between 1984 to date, in what is the care of victims of political repression during the civic-military dictatorship in Chile, the transgenerational damage and the trauma of political and
} 
The idea of justice has been shown explicitly or within other notions, especially concerning human rights and in those currents that have been structured, in the words of Habermas, under the idea of emancipatory interest, linked to self-determination and autonomy before any foreign power that wants submission (Habermas, 1982). That OT that not only reflects on the issue of power but also social transformation as a premise for freedom and emancipation, necessarily considering, from our Latin American place, the ideas of coloniality, racialization, gender, class, and interculturality.

In this practical and theoretical field of OT with critical orientation, the idea of justice has been understood, assumed, and named without an adjective, from its substantivity, as Justice. In the same way, and without detaching from this substantivity, concepts have used that focus on certain scenarios of social conflict, but that does not point to a particular profession, but to dimensions of social reality that need to be faced, deconstructed, studied from several subjects, or, used for the politicization of the transforming task. Critical OT refers in its praxis to social justice, cognitive justice, civil justice, among others, but not as a category equivalent to an object of study that defines a job, a profession, a task that can be called scientific, as is the case of occupation, but as a political category for the political action of the profession.

So, it is worth asking, why occupational justice (OJ) and not justice only? or Why OJ in Latin America?

The issue is to historically locate the categories to understand their context of meaning and use since for the Anglo-Saxon world the concept of $\mathrm{OJ}$ as situated production probably accounts for their socio-historical processes as occupational therapists. In this sense, it seems necessary to reflect on its relevance for those of us who assume critical Latin American perspectives in OT and discuss its foundations and implications of the use of the OJ concept in historical contexts such as ours. It is worth asking whether or not we should embrace these new notions.

\section{Some Reflections on the Idea of Justice}

Referring to Justice is to consider an idea of what is fair. A notion that comes from political philosophy, which studies the relationship between the subject and the social, power, freedom, equality, democracy (Swift, 2016). All this is strongly linked to the ethical. These ideas of political philosophy have varied according to historical periods, depending on the concrete conditions of social production. That is to say, its foundation is sustained from concrete, situated, and historical social praxis, which tries to answer how we can live together in society.

From modern political philosophy, in a very general way, it has been put into play - as a central theme of the idea of justice - whether the duties and rights fall on the individual or the community. In the first, as individual moral dignity, which translates into what has been called methodological individualism ${ }^{4}$ and, in the second, in the communitarian, which understands dignity as a common good. Thus, the idea of what is fair will be

social violence in the post-dictatorship period. Many of the written articles, book chapters and monographs can be found at Centro de Salud Mental y Derechos Humanos (2020).

${ }^{4}$ It refers to collectivities as composed of individuals. "Wholes have to be understood in terms of the parts that compose them-and societies are made up of individuals. The events and states that are the object of study in society are ultimately formed by events and states of the individual components" (Taylor, 1990, p. 178). 
materialized as primarily individual freedoms or as any individual freedom that occurs within the reference of belonging to a community (Rodríguez, 2010) respectively. From a critical political philosophy, proposals of another order have been made on the idea of justice that implies a break with modern Eurocentric rationality, of a liberal, and individual order, and that is based on an ethic of liberation and a praxis emancipatory (Dussel, 2001).

What is fair? What is unfair? It is nothing less than the moral valuing of being well together and fundamentally of an ethical-ideological nature. That is the fair as an indeterminate that is based on world ideas, on a belief system that constitutes rationalities. These ideas of what is fair, delimited in its borders, in its scope, will be translated into ideas of justice. As Taylor points out, there is a distinction between concept and conceptualization (Donoso, 2003). What is fair is the concept, the possible conceptualizations are varied and thus the ideas of justice varied.

In other words, there is not a single idea of justice. Modern political philosophy in its controversies has raised a variety of theories of justice, from individual liberalism, social liberalism to communitarian theories, legal pluralism, among others. Each one is based on a belief system of fairness, power and freedom, equality, inequality, community, and individual.

\section{About the Idea of Occupational Justice}

Regarding the idea of OJ, the first thing is to point out that it is a neologism that articulates justice with the occupation, proposing the ideas of justice and occupation as universal. In other words, occupation is a transversal notion, generalized to all places, times, and conditions of OT practice. Following the discourse of law and justice, the foundation also assumes a natural law and functional condition of the occupation.

But in this reflection, I will not point to the idea of occupation but to the idea of occupational justice, understanding that both articulated notions are based on a universalist and essentialist proposition.

Thus, the proposal is to understand the concept of Occupational Justice as a speaking act of a speaker. Every act of speech has a performative character, that is, it produces reality in the act of being enunciated. This statement, OJ, only has meaning in OT. Outside the discursive area of the job, it does not make sense. The OJ is nothing more than a signifier that means, within the reference of a place of speech that constitutes the concept. This place of speech - significant - is the North/Eurocentric OT, predominantly Anglo-Saxon, by this I mean, "European" in the sense indicated by Grosfoguel (2007 as cited in Montes \& Busso, 2007, p. 18):

[...] not to the population of the territory that we know as "Europe", it refers to a position in a racial classification system in a global ethnic-racial hierarchy where whoever is classified as "euro" will have privileges and accumulation of wealth superior to those who be classified as non-European" [...] a certain type of fundamentalist-Eurocentric thinking that does not recognize on an equal footing other epistemologies than its own and that does not see any other epistemology or cosmology as normal except its own, produces epistemological racism where only truth and justice are on the western side since non-western knowledge is considered inferior. 
From this conception, I understand the North/Eurocentric OT, as one that is in a position of political, cultural, epistemological superiority, sustained in one of its dimensions, in the technical-scientific development of rich countries, which do not recognize other cultural forms of knowledge on equivalence and supposes a superiority of science based on facts and evidence (in the logic of subject-object), where reality is the product of science and OT, as part of it, is a single one, delimited with borders. "If science tells us what the world is like, then the civilization that produced that science is, by force, superior to the civilization that did not produce it and was left with the myths" (Montes, 2017). The consequence is that everything that is not this way of understanding the world is left out, denied, as a zone of not being (Fanon, 1999). The North/Eurocentric is territorially distributed globally, like the modern Western world, with center and periphery. In our region, there is also North/Eurocentric OT, as, in territorial Europe, there is also Critical OT practice.

Returning to the idea of the place of speech of the North/Eurocentric OT, it assumes the place of knowledge from its historical condition, and from there, it constructs categories, new universalist grammars that suppose KNOWING for the job as a whole. In this action, the existence of other places of speech, other voices, pluralities, and dissidents is denied, which within the reference of their historical realities formulate other understandings of the idea of justice and the non-need for categories such as OJ.

As Immanuel Wallerstein tells us, in the capitalist world-system there is no homogeneity in any dimension of social life, both cultural, economic, or political (Grosfoguel, 2006). What happens is a dominant and hegemonic center of power, which establishes profound differences, but also, installs a hegemony, a power that denies multiculturalism, normative and legal systems other than those of modern liberal positive law. This normative system from the idea of individual justice sustained on an atomistic foundation, and it is the one in which the modern civilizing project has operated and continues to operate today. From the mere idea of property as a natural fact, the selfownership of libertarians, in utilitarianism and, lately, liberal egalitarianism, expressed as equalization of opportunities. In all of them, coloniality is its matrix.

Analyzed from this perspective, the idea of OJ produced by the North/Eurocentric occupational therapies corresponds to the capitalist center, in this case, a delocalized center, a center of several places at the same time: Canada, United Kingdom, Australia. In this sense, it is an overcoming of the single homogeneous center of Europe. However, they are new centers characterized by other historicities typical of rich countries, mostly extractivist, white, patriarchal, with universalist and homogeneous rationality, colonizing countries that have been sustained by the evolutionary discourse of progress and civilization.

In an article published in 2004 (Townsend \& Wilcock, 2004), the justice problems described by the idea of $\mathrm{OJ}$ are related to processes linked to migration derived from wars in which the imperialist countries have been part, the refuge, rural groups, marginalized people and communities, communities called aboriginal or OT experiences in countries of the periphery or called years ago as the third world.

The idea of OJ materialized around 2000 in the North/Eurocentric world, is strongly determined, in my opinion, by the increasingly growing expression of inequality and global injustice from the extreme accumulation of wealth as a consequence of savage capitalism and neoliberalism. It has the effect of increasing inequality of communities, groups, and individuals belonging to the peripheral world system. The great migrations from the 
periphery to the center, for reasons of impoverishment and precariousness resulting from savage extractivism in countries with colonial history, the so-called economic deregulation and financialization of the economy, the forced reduction of the State apparatus, a result of the agreements of Washington determined by the World Bank and the International Monetary Fund, the fall of the socialist world, with the consequent civil wars in Eastern Europe (the periphery of Europe), implied for the countries of the center of economic power, a forced adjustment of their social policies under the idea of reducing social inequality (social justice) from a liberal logic, with a subsidiary role of the State. This context challenges professions and subjects to adapt their categories and methodologies to intervene in the new social issue ${ }^{5}$. Faced with the new malaise and social suffering (poverty, exclusion, pain, disease, misery, inequality, injustice, indignity), the old and new professions (OT among them) as technologies of the forms of government, must adapt their conceptual-practical instruments for their performance. With its political and not primarily technical origin, OT is strongly interwoven with the development of public and social policies. Public policies have not only been the material context through which the current neoliberal system and the market society unfold, they have also technically articulated and configured the interventional practices implemented in the vast majority of professions. The OT has not been immune to this. That is, the new forms of approach to the new social question (which the North/Eurocentric OT has called occupational deprivation, occupational marginalization, occupational injustice, occupational alienation, among others), from public policies have operated in a significant way on the aspects technical and conceptual of the actions in OT (Guajardo Córdoba, 2016). We are no longer related to the disease, but the social issue and its link to health. The problems have been transformed into social objects of OT, studies, research, and construction of new concepts (occupational justice) and models (Occupational Justice Framework).

In the proposed OJ proposition, each individual has intrinsic capacities (talent), which can be favored or disturbed by social conditions. Therefore, the idea of fairness is to provide equal opportunities and capabilities for each person to decide individually what they want for their life (merit and autonomy in the strictly individual sense). In this consideration, the proposed path will be the training of abilities and skills, which in the idea of OJ has been called empowerment and influencing those social determinants, which the North/Eurocentric OT calls occupational determinants and which are expressed in injustice, deprivation, alienation, marginalization, imbalance, all of them "occupational". In this interaction, participation in fair occupations would impact good health. Underlying this conceptual methodological proposal, the idea of social determinants in the health of the WHO, participation of the International Classification of Functioning - CIF-WHO -, with the liberal political idea of the individual.

The proposal of the OJ, as I have proposed, materializes the place of speech of the modern colonial world in the Anglo-Saxon OT and constitutes the foundation of this concept. The historical-epistemological horizon in which it is situated, embodied, is the one that establishes limits so that other ideas of what is fair, worthy, or good living, of other options or historical-cultural possibilities of what justice can be. This limit is the instrumental, individual, and liberal technical rationality of the idea of $\mathrm{OJ}$ and transforms

\footnotetext{
5"[...] a fundamental aporia (a problem that is difficult to solve) in which a society experiences the enigma of its cohesion and tries to avoid the risk of its fracture. It is a challenge that interrogates, puts into question the capacity of a society (what in political terms is called a nation) to exist as a group linked by interdependence relations" (Castel, 1999, p. 16-17).
} 
it from a situated notion to a universal one and from the central world system to the periphery. In my opinion, the idea of OJ is not a border concept, a vanishing point that can open the utopia of another possible world to capitalism. On the contrary, it is a new form of coloniality of knowledge, which reproduces forms of understanding the world from the North/Eurocentric perspective and, when doing it, denies other possible worlds at the same time.

The idea of OJ, which matryoshka doll effect, is an instrumental technical neologism that comes from social justice and is based on the philosophical the ideas of Jhon Locke, founder of liberal political philosophy, with the idea of the natural and inalienable of the rights and property as a condition of nature; in Kant, with the idea of a fully autonomous individual, pre-existing to any social reality; in John Ralws, with the theory of justice of liberal egalitarianism, expressed in the need to share and distribute goods in minimum morally accepted by all, as a condition of equality, constituting basic individual rights, able to exercise autonomy (this requires a neutral State that does not intervene in the individual will but that guarantees certain rights); and in Amartya Sen, with justice as a capacity that recognizes that people differ in how they transform the same means into different achievements and this is explained by the concept of capacity and the expansion of individual freedom based on the valuation that each individual has to achieve the life that each one wants (Swift, 2016). The synthesis of the above has become the central political notion of neoliberal states in the face of the new social issue: Justice as equality and equal opportunities.

OJ as equality and equalization of opportunities rests on the fact that the inequalities in the living conditions that separate each person would cease to be unfair because each person can have the opportunity to escape from them. "And since it is assumed either that individuals are all equal, or that their talents or merits have been randomly distributed, then, consequently, they must end up being distributed proportionally at all levels of society" (Dubet, 2011, p. 55). Each person has talents and opportunities must be created for people to earn credit and have the opportunity to compete on equal terms. This vision dilutes the equality of positions, expressed as social classes, the structural production of processes, the labor-capital relationship, gender, identity, and patriarchal positions, as well as positions situated and embodied in historical, cultural, and social processes.

However, equality of opportunities sees people, social groups in disadvantaged situations, violations, which limit their possibilities of objectively accessing social positions with more social, economic, and cultural capital (social mobility). This notion of equalization of opportunities has promoted a substantive modification of the social language to refer to people, groups, and communities from the aspects of structural positions in the process of social production to an individual view with favorable or unfavorable social determinants. We go from workers, settlers, poor people to underprivileged classes, disadvantaged groups, groups in a situation of vulnerability, deprived, precarious middle class, among other new nomenclatures.

From now on, popular neighborhoods are designated as disadvantaged or "difficult" neighborhoods, and even "sensitive". To a large extent, a "deodorization" of the popular categories is observed, in favor of more vague 
notions in which economic, cultural, and social factors, deprive individuals, especially children, of their opportunities to socially advance (Dubet, 2011, p. 58)

They are new forms of victimization, of subalternation of the capitalist neoliberal project, which dilutes the relationship of the individuals in their relationship with work capital, to a logic of discrimination and identity.

In the North/Eurocentric OT in the idea of OJ, the injustice would be:

Denial of universal access to opportunities and/or resources to participate in culturally unfair defined health recovery occupations. Also, the lack of enabling practices focused on the client restricts the opportunities and/or resources necessary for different people to participate in the occupations of a society (Townsend \& Wilcock, 2004, p. 76).

Occupational injustice is the articulation and expression of 5 parts: occupational apartheid, occupational deprivation, occupational marginalization, occupational alienation, occupational imbalance (Durocher et al., 2019).

As we can see, there is a translation into the professional technical language of the job, of processes of historical, philosophical, ideological, political, and economic order, among others. It implies that what is thought about something is given under certain conditions of historical production and not outside of it. Using the ideas of Bourdieu (2001), the North/Eurocentric OT area produced under these historical conditions has constituted a habitus based on the idea of liberal justice that has produced a symbolic, cognitive capital of a variety of concepts in which performs its practical action: OJ, Occupational Participation, Occupational Injustice, Occupational Imbalance, Occupational Marginalization, among others. Like all capital, it is exchanged within the reference of power relationships in the logic of the center and the periphery. It must be assumed that we are the periphery. From a critical Latin American perspective, I could call this a new form of cognitive colonization, as pointed out by Sousa Santos (2012).

Now, from another angle, the North/Eurocentric OT poses the OJ as an emerging and increasingly complex notion - the Evolutionary Theory of Occupational Justice (Durocher et al., 2019), questioning and accompanying the work of different occupational therapists in the world. As a consequence of something new in the profession: the ethical and political questioning derived from the occupational injustices experienced by the people with whom we work. It is evident in this proposition that something new, very new, is being discovered: the complexity of the world and how difficult it is today to sustain technical neutrality and the asepsis of scientific endeavor. That new problem requires new categories to interpret them, the appropriate concepts will allow us to better objectify the new existing reality and thereby be able to act to modify them. We require new concepts for new realities. That is the thesis, since the correct methods, techniques, and instruments, guides for practice, will derive from it. Illich (1981) has called it the methodological bureaucracy of the scientific professions that as a consequence leads to a disabling of citizenship, underlying this conceptualization is the technocratic, positivist, objectivist substrate of this OT. 
The foregoing would suppose, for example, that in Latin America injustice is also a new, very new issue. I think it would help to demystify this by reading the book "The Open Veins of Latin America", by Eduardo Galeano, to realize that in our territory, since the act of colonization, injustice has been one of its paths. OT in our region comes from the center of injustice, it is the injustice experienced by the so-called Global South. Of course, since we are not the world, this does not exist, it is non-existent. It is the abysmal thinking described by Sousa Santos (2012). Like any North/Eurocentric position, this new reality is supposed to be new for everyone, since the world is none other than the North/Eurocentric.

Another aspect that I think is necessary to reflect is the translation of the category of political philosophy, Justice, to a technical methodological term, OJ. We can say that there is a kind of paradox in this regard since what we could suppose as a politicization of the job and the ethical consideration of it, implies a de-politicization of the notion de facto since it entails a technocratization of the concept. It is not political rationality in which the profession is inscribed, but a technical concept of a methodological nature, technical-instrumental rationality. Justice is no longer a common citizen exercise issue, which debates what is fair, but rather a reference, with a procedural logic, that allows OT action to better fulfill its objective so that employment as a tool and way to improve health condition. Thus, to be able to investigate and produce scientific knowledge rather than political praxis. Therefore, the adjective Occupational displaces the noun Justice. Not a grammatical noun, of a word that names, but of constitutive, of substance, of foundation, which becomes the possibility of establishing work models, such as the OJ Reference, which, together with the Canadian Model of Occupational Performance, allows the therapeutic action rather than the need for social transformation. Guidelines, evaluation techniques, and procedures can be created to identify injustices and address them; it is atomism ${ }^{6}$. Social inclusion without structural transformation is intended. To include in the world system that has generated exclusion.

For the political there is social justice, for the profession, there is occupational justice. This binarism is based on social justice and OJ are different; the first, of a social nature and the second, of an occupational nature. This is not a redundancy, but an effective belief of an ontological nature of the North/Eurocentric OT and, at the same time, an administrative delimitation of a union nature. Social justice is an equal redistribution of social rights and the OJ of occupational rights, particularly in participation in diverse and significant occupations. They are arbitrary demarcations of a technical discourse that tries to support the idea that there is something that only belongs to OT and no one else. The complexity of social reality can be approached from a delimited and precise territory of a profession in a pure way (atomism-positivism). Complementing this claim is the fact that the OJ neologism is introduced into a new network of OT terminologies, one that acquires a diverse, but not necessarily different format: occupational rights, occupational determinants,

\footnotetext{
'In philosophy, atomism will understand that wholes "[...] have to be understood in terms of the parts that compose it and societies are made up of individuals." Atomism affirms that each subject operates individually and, therefore, has the right to choose his own plan of life. This is what is called individual autonomy (Donoso, 2003). Also, this atomistic idea can make us understand the idea that a delimited profession is possible, with its own concepts with its own object of study, with its own technical grammar. So, the OJ is made up of parts, each pointing to a specific aspect of the OJ idea. As well as understanding that the OT individual is made up of parts or, the action or activity of that individual is also expressed in parts in what have been called performance areas.
} 
occupational participation, occupational injustice, occupational exclusion, and a generalized and trivialized universal, to infinity and beyond. The possible, unwanted effect of all this is a new form of depoliticization of OT and the reaffirmation of its scientificity and its technical-instrumental-functional scope.

As for the subject of OJ, he is a lacking individual, without resources, who needs to be empowered from the outside, to be trained. He is located in the place of not being (Fanon, 1999), of subalternity, which requires to be assisted and empowered. What is called "customer-centric" does not imply political symmetry. Establishing a relational symmetry to the user satisfaction model is not equivalent to human rights. In this logic, there is no reciprocal recognition, that is, that the person with whom I work, his injustice, is the result of a social relationship in which I am part and I recognize myself in this relationship of injustice and not in a technical outside. Centrality, it is what people need and what they want to do in the strictly liberal sense, assuming certain cultural particularities of each individual and recognizing the diversity of values and interests (we have pointed out the role of Sen's capabilities approach) oriented towards social inclusion. In this sense, we must reaffirm that the human rights approach displaces the needs approach since the rights are highlighted and not primarily on the overcoming of needs. Beyond capabilities, the individual is the right and does not require enabling capabilities to be considered an individual of law (Guajardo Córdoba \& Galheigo, 2015).

\section{As a Synthesis and Proposal}

We can point out that the idea of liberal justice and in it the OJ show an incomplete view and do not solve the problems of the current world marked by the precariousness of life and its consequent dehumanization, expressed in inequity and growing inequality among the rich and poor, between the capitalist center and the periphery. By reducing the problem of justice to the fair distribution of goods, in the case of OT to access to meaningful occupations, to so-called occupational rights or the strengthening of occupational capacities, "[...] without considering the causes that determine social inequalities and structural asymmetries in the power relationships of the current capitalist order" (Cortés Rodas, 2010, p. 2), the OJ ends up affirming the fundamental principles of the colonial patriarchal capitalist system of domination. In this sense, the criticism of the idea of OJ, according to which the end is participation in significant occupations does not affect at all the systemic aspects of capitalist power that are marked by the power relationship between center and periphery, which is properly the cause of social inequalities and the growth of poverty and the so-called occupational injustices and deprivations, what I have called the new social question in OT. To the extent that extreme inequality and poverty in today's world are the results of a complex system of power relationships between rich and poor countries, which are also reproduced at the local level in particular countries and communities, think about focal relief, solutions in particular individuals, which undoubtedly imply the reduction of the problem at a singular level and a specific relief, expressed in the language of the North/Eurocentric OT as basic occupational rights, or ensuring basic human capacities in what has been called empowerment. But without questioning or seeking to modify the system of power 
relationships of the current capitalist order, it can lead to a certain improvement in the social condition of the well-being of individuals, as I have indicated, but not to an overcoming of the structural relationships of power and domination that determine and reproduce the situations of poverty and dependency in the world from the patriarchal colonial capitalist system. It is to overcome the contradiction of social inclusion in a social system that, in its essence, is exclusive. Being part of a shared, social, political community, which we could call inclusion, seems to me to require that the dominant social system be transformed simultaneously and at the same time in this process.

The proposal of what I have proposed as a Latin American critical OT, based on the idea of fairness as a common and not individual good, can be sustained on the statement of Good Living, but please, not good occupational living, but Good Living as a community, assuming an anti-colonial, anti-patriarchal and anti-capitalist logic.

It implies recognizing territoriality and a particular identity, assuming that we are heterogeneous in the Abya Yala community ${ }^{7}$, which proposes an end of the world, of the coloniality, for another possible world, which fractures the idea of OJ as a positive moral normative statute of the task of Occupational Therapies, the monocultural idea of justice. It implies that the idea of what can be considered fair and justice is within the reference of cultural plurality, in recognizing various normative forms, many of which are expressed not as positive legal acts, but as everyday practices of forms of life where the central element, assuming the value proposed by indigenous communities of the southern cone of America, is Reciprocity ${ }^{8}$. Justice as a community act, as a pattern of relationship for collective harmony. It is about decolonizing the idea of modern North/Eurocentric justice, based on a plural, intercultural dialogue that resolves the forms of injustice from various inter-epistemic logic (ecology of knowledge). This has been approached in a very interesting way by legal pluralism (Alanís de la Vega, 2018)

Thus, it is necessary to assume an ethical-political - epistemic vigilance with the AngloSaxon - North/Eurocentric center (the OT in this center), to have a new horizon of possibilities, unfinished, always incomplete, since this is a condition of possibility of the human freedom, an understanding of emancipation that goes beyond the western world. Therefore, the idea of justice from an ethical utopia, not from modern instrumental technical rationality.

\footnotetext{
${ }^{7}$ At present, different indigenous communities, organizations and institutions have assumed the name Abya Yala to refer to "our America". It is recognized that this is the original name of the territory that ranges from Mexico to Andean countries and, that of America, as the name of colonization. It points to a territory without limits or borders and inhabited by a plurality of communities. Its name refers to "living land", "flowering land", "mature land". My intention is to give an account of the cultural plurality, of stories, of knowledge, which in common have the sign of reciprocity, of good living, of a close relationship with the land. My interest is the ethical, utopian principle of recovering this ideology of living well together in community, rejecting in this way the modern liberal civilizing project of individual autonomy unrelated to others, in the context of the free market and technical-instrumental rationality such as knowing and the idea of justice based on individual private property. Whoever wants a more comprehensive reading, I recommend the text Abya Yala: An indigenous vision. Written by a group of authors edited by Rolando de la Ribera (Mayoral, 2012).

${ }^{8}$ The idea of Reciprocity, which together with that of balance and social equity, constitute the ethical value of the indigenous communities of the Ecuadorian Andes. The idea of reciprocity refers to giving in order to receive. "It consists of the joint and supportive work contribution of all the members of a social group, in order to carry out a work of common interest ... it allows to maintain the interests of the community in the midst of a full expression of solidarity and redistribution internal and self-centered goods and services" (De la Torre \& Sandoval, 2004, p. 29).
} 
The struggle for an idea of fairness must assume an intersectional perspective, involving ethnical-racial, gender, and social class. In other words, the task should not be only equality, since it cannot be separated from the struggle for the recognition of the ethnic-cultural-gender-class difference. It should not be just because of diversity, since belonging to particular groups does not ensure political participation and recognition. On the contrary, the dominant world system manages and integrates cultural diversity into the market. Following Arendt, the political participation and the idea of being in public under an idea of fairness in the community are sustained under the premise of recognition of difference, the plurality as a "[...] condition of human action because we are all the same, that is, humans, and therefore no one is the same as anyone else who has lived, lives or will live" (Arendt, 1998, p. 22).

Thus, the main task is to politicize, historicize, deindividualize, recognize ourselves as part of a political community, where professional scientific work joins the set of social actors, in the ecology of knowledge, where OT praxis is not primarily the OJ, but rather a political ethical practice for the recognition of difference as practical, concrete value, politicizing the struggle for the difference to achieve the dignity of recognition. That is why it is correct to speak of Occupational Therapies, not in the sense of different ways of doing therapy under the same ontological foundation. The idea of Occupational therapy is based on the idea of an OT Other', in the sense of effective difference, of a radically different otherness. An OT whose first philosophy is political ethics is different in a radical sense, from an OT where its first philosophy is ontological-epistemic. Both are of a different order. From this perspective, all controversy and dissent are necessary since we are in a field always in a dispute over the decolonization or coloniality of the profession and the subject.

We as Occupational Therapists, together with those affected, victims, excluded from the community of life, must become aware of our position, mutually questioning each other to constitute a critical community in which, discursively and in a concrete practical way, a negative judgment of the system is based that has caused them, and a utopian, possible, real, historical alternative is proposed against the system of oppression. OT practice must deny the system that denies the possibilities of humanity. We are the result of the institutional apparatus that denies the existence, so we must deny what we are to be an OT Other.

More than new concepts (the OJ, in the case of this writing) and its methodological drifts (work references), the ethical-political rationality of professional and disciplinary praxis is required. A practical operation of experiencing in the world of daily life, in the concrete human activity of people and groups, the possibility of building community and personal moral projects under an idea of plural and intercultural justice in the concrete making of daily life, in the reference

\footnotetext{
${ }^{9}$ I refer to Other Occupational Therapy, to the idea put forward by Walter Mignolo Paradigm Other, which refers to the diversity of critical forms of analytical thought and future projects based on the stories and experiences marked by coloniality, rather than by those dominant up to now based on the stories and experiences of modernity. "The 'other' paradigm is, ultimately, critical and utopian thought, which is articulated in all those places in which the imperial/colonial expansion denied it the possibility of reason, of thought and of thinking about the future" (Mignolo, 2003, p. 20). It is to think, effectively, the rupture and abandonment of the modern, western matrix, of technical-instrumental rationality of the North/Eurocentric OT and to consider a foundation of another order that is not another OT derived from the dominant rationality of OT, but a radically different, built from another concrete location, which abandons the modern liberal civilizing project and is situated in the bodies of the excluded as the place of its action.
} 
of a shared public community, in what I call practical self-determination, within the reference of belonging to a particular political community.

I propose that the political rationality in OT should be sustained primarily under ethical criteria, not academic, scientific, or professional technical. Taking the ideas of Enrique Dussel (2001, p. 28):

The enunciation of the critical-material principle of ethics that imposes that the affirmation of life requires the criticism of all systems in which the corporality and dignity of the other are denied. All ethical criticism emerges from the recognition of the suffering of others. However, this suffering is always material and bodily. The condition of the possibility of all criticism is the recognition of the dignity of the other subject, the co-subject, but from the perspective of their being, seen and experienced above all as living human beings. In this way, we have a critical material principle that can be stated approximately like this: every institutional system (or act, etc.) that does not allow its victims to live, potential members denied, excluded from the system that claims to reproduce life, must be criticized. The "duty" of criticism, as a negative material universal judgment, is the beginning of the entire process of "development" or "transformation" of human life in historical systems as the liberation of the victims.

From a decolonial reading, this ethic can be expressed, as I have already pointed out, in the idea of Good Living/Living Well, recognizing that there is much Good Living. That is, many alternative and practical notions of how to build decolonial communities. The idea of "Good Living allows the reinforcement of identities, and for many cultures, their essences are put into play, and not their margins" (Gudynas, 2011, p.11). Good living from their plural and intercultural condition will always be hybrids, networks, they will not be homogeneous or universalist, always historically situated, with multiple forms in embodied stories under the ethical premise of reciprocity. Coexistence may be expressed in human rights as cultural production, but not in the dependence primarily on the legal norm, but in a way of life-based on recognition. Thus, every time a human right based on an idea of justice is claimed, we must ask about the structural aspects, of social and cultural relationships that make a dignified life, including nature, be constituted (Gándara, 2019).

This will translate into the possibility of various ideas of justice, which can converge in a common minimum, that is, human rights, assuming that their origin has a strong Eurocentric liberal inspiration, which requires a reformulation of them so that they do not constitute new forms of western colonization. To do this, it is necessary to think of a world from a perspective of a plurality (difference), which leads us to think of human rights from an intercultural logic, confronting all forms of abstract and homogenizing universalism (Sousa Santos, 2013).

In this way "Good Living will require that people, communities, villages, and nationalities effectively enjoy their rights, and exercise responsibilities within the reference of interculturality, respect for difference and harmonious coexistence with nature" (Zaragocin, 2017, p. 30). It implies affirming the need to recognize the diverse experiences of different cultures, appreciating in them how the idea of dignity and the values linked to it are present. 
Finally, faced with the generalization of the idea of OJ, from a critical historical perspective, we are obliged to understand it as a particular notion of the place of speech of the North/Eurocentric OT that, located in the center of the world system, constitutes a universalism monocultural of the idea of justice and its application in the job. This particularism responds to a situated reality that is not ours and is characterized by being of the colonizing, rich, capitalist, extractivist, white, liberal, patriarchal countries, of technical-instrumental, and scientist rationality. This particularism shown as universalism in global OT is built in a new form of coloniality of being, knowing, and doing. It reaffirms the individual gaze, of paradigmatic, technocratic, depoliticized, and ahistorical bias of the North/Eurocentric occupational therapies, expressed in a liberal vision of the idea of justice, of human rights, and the practices supported from this political-philosophical perspective.

The invitation is to assume an OT Other, a militant OT, based on an ethics of excluded otherness, an ethic of liberation, expressed in the idea of good living, of culturally situated and embodied ideas of justice, from a decolonial legal plurality, promoting human rights from a reading that allows the permanent construction of interculturally accepted conditions, which lead the individuals to consider and produce, from their situated, incarnate historical positions, the possibility of formulating and constructing worlds that collect their different horizons from reciprocity and contexts.

\section{References}

Alanís de la Vega, E. (2018). El pluralismo jurídico: apuntes para un enfoque antropológico, material y descolonial. Revista Direitos Humanos \& Sociedade, 2(4), 114-133.

Amnistía Internacional. (2019). Manual movilizando la diversidad. Chile.

Arendt, H. (1998). La condición humana. Barcelona: Paidós.

Bourdieu, P. (2001). Poder, derecho y clases sociales. Bilbao: Desclee Editorial.

Castel, R. (1999). La metamorfosis de la cuestión social. Buenos Aires: Paidós.

Centro de Salud Mental y Derechos Humanos - CINTRAS. (2020). Recuperado el 27 de julio de 2020, de http://cintras.org/publicaciones.htm

Cortés Rodas, F. (2010). Una crítica a las teorías de Justicia Global: al Realismo, a Rawls, Habermas y Pogge. Ideas y Valores, 59(142), 93-110. Recuperado el 27 de julio de 2020, de https://revistas.unal.edu.co/index.php/idval/article/view/36600/38521

De la Torre, L., \& Sandoval, C. (2004). La reciprocidad en el mundo andino: ei caso del pueblo de Otavalo. Quito: Editorial Abya-Yala.

Díaz, M. (2020). Controversias y debates contemporáneos en comunidades de terapeutas ocupacionales de América Latina entre los años 2010-2018: rastreando puntos de convergencia y divergencia y sus conexiones con procesos históricos situados (Manuscrito no publicado). Universidad Humanismo Cristiano, Universidad Federal de San Carlos.

Donoso, C. (2003). Charles Taylor: una crítica comunitaria al liberalismo político. Polis, 6, 1-22. Recuperado el 27 de julio de 2020, de http://journals.openedition.org/polis/6775

Dubet, F. (2011). Repensar la Justicia Social: contra el mito de la igualdad de oportunidades. Argentina: Siglo XXI Editores.

Durocher, E., Gibson, B., \& Rappolt, S. (2019). Justicia Ocupacional: una revisión de conceptos. Journal of Occupational Science, 21(4), 418-430. http://dx.doi.org/10.1080/14427591.2019.1616359.

Dussel, E. (2001). Hacia una filosofía politica crítica. Bilbao: Editorial Desclée. 
About new forms of colonization in occupational therapy. Reflections on the Idea of Occupational Justice from a critical-political philosophy perspective

Fanon, F. (1999). Los condenados de la tierra. Navarra: Txalaparte.

Gándara, M. (2019). Los derechos humanos en el siglo XXI. Una mirada desde el pensamiento crítico. Buenos Aires: CLACSO.

Grosfoguel, R. (2006). Del final del sistema mundo capitalista hacia un nuevo sistema histórico alternativo: la utopística de Immanuel Wallerstein. Revista Nomadas, 25, 44-52.

Grupo Ocupación y Realización Humana. (2011). Ocupación: sentido, realización y libertad: diálogos ocupacionales en torno al sujeto, la sociedad y el medio ambiente. Bogotá: Universidad Nacional de Colombia

Guajardo Córdoba, A. (2016). Lecturas y relatos históricos de la terapia ocupacional en suramérica: una perspectiva de reflexión crítica. Revista Ocupación Humana, 16(2), 110-117. http://dx.doi.org/10.25214/25907816.141.

Guajardo Córdoba, A., \& Galheigo, S. (2015). Reflexiones críticas acerca de los derechos humanos: contribuciones desde la terapia ocupacional Latinoamericana. World Federation of Occupational Therapists Bulletin, 71(2), 73-80. http://dx.doi.org/10.1179/1447382815Z.00000000023.

Gudynas, E. (2011). Buen Vivir: germinando alternativas al desarrollo separata: destaques del FSM. Ecuador: Agencia Latinoamericana de Información.

Habermas, J. (1982). Conocimiento e interés. Madrid: Taurus.

Illich, I. (1981). Profesiones inhabilitantes (Serie Crítica/Alternativas). Madrid: H. Blume Ediciones.

Lopes, R. E., \& Malfitano, A. P. S. (2016). Terapia ocupacional social: desenhos teóricos e contornos práticos. São Carlos: EdUFSCar.

Mayoral, M. J. (2012). Abya Yala: una visión indígena. Mexico: Prensa Latina.

Mignolo, W. (2003). Historias locales/diseños globales: colonialidad, conocimientos subalternos y pensamiento fronterizo. Madrid: Akal Editores.

Montes, A., \& Busso, H. (2007). Entrevista a Ramón Grosfoguel. Polis, 18, 1-13. Recuperado el 27 de julio de 2020, de http://journals.openedition.org/polis/4040

Montes, S. (2017, Junio 5). Pensar la ciencia desde lo latinoamericano: de Bunge a Kush. Diario Contexto. Recuperado el 27 de julio de 2020, de

https://www.diariocontexto.com.ar/2017/06/05/pensar-la-ciencia-desde-lo-latinoamericano-debunge-a-kusch/

Navarrete, E., Cantero, P., Guajardo Córdoba, A., Sepúlveda, R., \& Moruno, P. (2015). Terapia ocupacional y exclusión social: hacia una praxis basada en los derechos humanos. Chile: Segismundo Editorial Segismundo.

Oyarzun, S. N., Zolezzi, G. R., Núñez, S. J., \& Palacios, T. M. (2012). Hacia la construcción de las prácticas comunitarias de terapeutas ocupacionales en Chile, desde una mirada socio histórica, desde 1972 hasta la actualidad. España: Editorial Académica Espańola.

Paganizzi, L. (2007). Terapia ocupacional psicosocial. Buenos Aires: Docta.

Rodríguez, B. (2010). Liberalismo y comunitarismo: un debate inacabado. Revista de Humanidades, 16, 201-229.

Santos, V., \& Donatti, A. (2014). Cuestiones contemporáneas de terapia ocupacional en América del Sur. Curitiba: Editora CRV.

Simó, S., Guajardo Córdoba, A., Correa, F., Galheigo, S., \& García, S. (2016). Terapias ocupacionales desde el Sur. Santiago: Editorial USACH.

Sousa Santos, B. (2012). Una epistemología del Sur. Argentina: CLACSO.

Sousa Santos, B. (2013). Descolonizar el saber, reinventar el poder. Chile: LOM Ediciones

Swift, A. (2016). ¿Qué es y para que sirve la filosofía politica? Argentina: XXI Siglo Veintiuno Editores.

Taylor, C. (1990). El atomismo, en Derecho y moral: ensayos analíticos. Revista de Ciencia Política, $12,1-2$. 
About new forms of colonization in occupational therapy. Reflections on the Idea of Occupational Justice from a critical-political philosophy perspective

Townsend, E., \& Wilcock, A. (2004). Occupational Justice and client-centered practice: a dialogue in progress. Canadian Journal of Occupational Therapy, 71(2), 75-87.

Zaragocin, S. (2017). Feminismo decolonial y buen vivir. In S. Varea \& S. Zaragocin (Eds.), Feminismo y buen vivir: utopias decoloniales (pp. 17-25). Ecuador: PYDLOS Ediciones Universidad de Cuenca.

\section{Corresponding author}

Alejandro Guajardo Córdoba

e-mail: alejandro.guajardo@usach.cl 


\section{Erratum}

\section{Erratum}

In the article "About new forms of colonization in occupational therapy. Reflections on the Idea of Occupational Justice from a critical-political philosophy perspective", DOI number https://doi.org/10.4322/2526-8910.ctoarf2175, published in Cadernos Brasileiros de Terapia Ocupacional, vol. 28, no. 4, p. 1365-1381, 2020,

On page 1365, in the article translated titles, where it reads:

Sobre as novas formas de colonização em terapia ocupacional. Reflexóes sobre Justiça Ocupacional na perspectiva de uma filosofia política crítica

It should be read:

Sobre as novas formas de colonização em terapia ocupacional. Reflexões sobre a ideia de Justiça Ocupacional na perspectiva de uma filosofia política crítica 